\title{
Comment: Interdisciplinarity? A definite maybe
}

\author{
STUART JENKS
}

Editors' note: This contribution arose from the conference at Avaldsnes on German merchants in the North Atlantic which gave rise to the present volume. It reflects upon both that conference and the problems of future interdisciplinary work on this subject.

\begin{abstract}
Noticed a very strange thing ... went to this conference
in Avaldsnes last week and realised that among all the

archaeologists present, not one had a watch! What's up with

that? And what does that say about our perceptions of time?
\end{abstract}

Michèle Hayeur Smith (6. June 2013)

Jenks, S. 2019. Comment: Interdisciplinarity? A definite maybe. AmS-Skrifter 27, 291-302, Stavanger. ISSN 0800-0816, ISBN 978-82-7760-183-0.

\begin{abstract}
The problems of undertaking interdisciplinary research, particularly in the fields of history and archaeology are considered. A series of five issues are identified which make it difficult to integrate studies from these two areas: knowledge mismatch, a mismatch of chronologies, an inability to match types of information, problems of the scale of study and issues around the maturity of the disciplines. Each discipline tends to enforce the particularities of its own vision, training students to its perspective and perpetuating the differences. Interdisciplinary is not, however, a doomed pursuit, and is likely to be most successful when there are clear and immediate benefits for all the parties.
\end{abstract}

Stuart Jenks, emeritus of the Department Geschichte, Universität Erlangen, Kochstr. 4, D-91054 ERLANGEN, GERMANY. E-mail: stjenks65@gmail.com

Keywords: fossil insects, cereals, stockfish trade, North Atlantic, ports, shipwrecks

The fact that all the historians present at the conference did have a watch was not the only strange thing that impressed itself on me in Avaldsnes. At the risk of over-egging the pudding, I think it would be fair to say that the archaeologists and historians viewed one another as being altogether just a little bit strange. ${ }^{1}$ And that set me to thinking about what prerequisites would have to be fulfilled in order dispel this sense of strangeness and allow interdisciplinary work between archaeologists and historians to flourish. ${ }^{2}$ Clearly, each of us, at the least, needs to understand the point of view and the approach of the other's field. ${ }^{3}$ Equally clearly, this was not the case in Avaldsnes nor indeed in any interdisciplinary conference I have ever attended. And the reason for that is that quite generally separate disciplines simply do not mesh with one another automatically or effortlessly, and no amount of exhortation (or New Year's resolutions) to cooperate with one another will alter that. An exchange of ideas between scholars from different fields, not to mention fruitful cooperation between academic disciplines, will only succeed if we acknowledge and explore the dissonances and frictions which arise when they are brought into contact with one another. As a preliminary contribution to such a wide-ranging discussion, I would like to spotlight five areas in which historians' and archaeologists' gears fail to mesh.

\section{Knowledge mismatch}

Each field employs its own technical vocabulary, which utterly mystifies the practitioners of the other. To take but one example: at the Avaldsnes conference, the historians were at a loss as to what archaeological 
terms like 'tephra' or 't-value' might mean, and the archaeologists were equally bamboozled by historical terms like 'the putting-out system', so that much explaining was needed. I hasten to add that I do not intend to impute that a coven of jargonauts deliberately employed obscure insiders' terminology with malicious intent. Rather, this is just one instance of a pervasive problem one commonly runs into when speaking with those outside one's own field, be they students or laymen, one which I have termed Expertenblindheit in German. Experts in a field are simply blind to others' blind spots and - in all innocence - cannot imagine that there is anyone in the audience, or indeed anywhere in the world who does not understand this or that technical term. Now, of course, this mismatch is easy to avoid, simply by having the papers vetted in advance and obscure terms red-flagged, so that they can be defined for those in the dark.

\section{Time-frame mismatch}

Archaeologists are perfectly happy with broad time frames. While 'Between 1400 and 1700' is exact enough for them, ${ }^{4}$ it drives historians to drink. They want to know the precise year, better the month, best of all the day something happened. Indeed, they spend what must seem to archaeologists to be an inordinate amount of time arguing back and forth about the precise date of an event or a document, in the end generally arriving at a consensus on the balance of the evidence. Needless to say, archaeological finds do not lend themselves as a rule to this sort of precise dating. Indeed, the archaeologists would $\operatorname{add}^{5}$ that they have made an asset out of a seeming liability, since their broad time scale enables them to capture important long-wave phenomena which remain invisible to historians. ${ }^{6}$ Now, I do not think that there is a solution to this mismatch, since it is rooted in the sort of evidence each field feels called upon to analyse in the first instance - I will return to this point below - but it is important for each side to realise why the time-frame preferred by the other side is appropriate for that field.

\section{Information resolution mismatch}

While archaeologists are perfectly happy with statements like 'in the written sources thus-and-such is recorded', historians want to know (1) Which source in particular? (2) What is the exact wording of the source in the original language? (3) Can we convince ourselves beyond a reasonable doubt that the passage in question will bear the interpretation given to it and that other possible interpretations can be ruled out of court? The reason archaeologists are content with fuzzy statements about written sources is, of course, that they merely provide a general background to the finds, which are what archaeologists really want to talk about and, in any event, it would be difficult, indeed usually impossible, to link up archaeological finds and written sources in a manner which would satisfy historians' stringency criteria. As Rolf Hammel-Kiesow has often pointed out, even though we know the name of every owner of every property in Lübeck between 1284 and the early modern period, we still cannot name the person who wore the shoes we find in the latrine on the premises with any confidence at all. If this holds true for a town with optimal historical records, then it surely holds doubly true for archaeological sites off the beaten track with virtually no written records. From the archaeologist's point of view, it just doesn't make sense to be precise. Again, I do not think that there is a solution to this mismatch, since it, too, is rooted in the sort of evidence each field primarily analyses, but we need to be aware of the reasons underlying blithely irresponsible fuzziness and precision fetishism if we are to talk to one another.

\section{Macro-micro mismatch}

Unless they investigate failed settlements - Gásir in Iceland or Haithabu in Germany - archaeologists only catch a very limited glimpse of the whole picture. After all, it is simply impossible to levitate Lübeck or London for five years and see what might be lying in the earth underneath the houses. Being firmly rooted in the micro level, archaeologists display a tendency (which dismays the historians) to leap to far-reaching conclusions on the basis of a minimum (again, from the historians' perspective) of evidence. ${ }^{7}$ That is to say, the leap from the micro to the macro level is (from the historians' perspective) disturbingly easy for the archaeologists. This mismatch is rooted in the evidence which each field feels called upon to analyse in the first instance, a subject to which we must now turn.

Historians firmly place the public records at the focal point of their interest. These records, particularly those from the Middle Ages, overwhelmingly tend to spotlight the most prominent members of society. Thus, there is vastly more information available in the written sources about kings, dukes and bishops than 
about ordinary labourers in town or peasants in the countryside. ${ }^{8}$ By way of contrast, archaeologists in northern Europe are most likely to turn up evidence of everyday life, that is to say the traces left in the soil by people too obscure to have left any in the surviving public records. There are, to be sure, prominent exceptions. After all, Richard III's skeleton was discovered under a car park in Leicester and bishops are found buried in their ecclesiastical vestments in cathedrals, but this is anything but an everyday occurrence in archaeology. Consequently, while archaeologists and historians contend that they are interested in the same people - those who lived, say, in the Middle Ages - in fact their evidence turns up traces of very different people. Therefore, the historians' big picture (the res gestae of kings, nobles and bishops) does not mesh very well at all with the archaeologists' micro finds (the detritus of ordinary people). Consequently, it is understandable that the archaeologists grumble that historians fail to deliver the goods on the people on whom they would dearly love to have some information from the written sources. And the historians grumble that the archaeologists leap to far-reaching conclusions on the basis of slender evidence, ${ }^{9}$ something that neatly matches archaeologists' grumbling that historians draw farreaching conclusions on the basis of sources which may be biased by incomplete recording at the outset and the vagaries of survival in the meantime. Now, I do not think that there is a solution to this mismatch. After all, we are all at the mercy of our sources. If they, by their very nature, do not mesh with one another, then we shall simply have to accept that neither field sheds much light on the other.

There is, however, an additional aspect of the macro-micro mismatch, namely that my macro is not your macro. Let me illustrate this point by citing the example which exercised us in Avaldsnes. In terms of overall Hanseatic trade, the North Atlantic played only a very minor role. Consequently, this trade generated comparatively few records, most of which have disappeared in the meantime. Therefore, no historian is in a position to say very much at all about Hanseatic trade with Iceland, Shetland, the Faeroes and so forth. In short, the Hanseatic historian's big picture does not include much more than a dab or two from the North Atlantic. However, from the reverse perspective - looking from Iceland, Shetland or the Faeroes - Hanseatic trade looms very large indeed. ${ }^{10}$ The Icelandic (Shetland, Faeroese) historian's big picture is comprised, to a large measure, of Hanseatic brush strokes. This macro-macro mismatch may be frustrating, but it is unavoidable, given the scope of the surviving sources.

\section{Maturity mismatch ${ }^{11}$}

Compared to history, archaeology is a fairly young science. To take but one example, 1871, when Schliemann began his excavations of ancient Troy, was also the year Leopold von Ranke, having lost his sight, resigned his chair in Berlin after almost fifty years of teaching (1825-71). While von Ranke is accounted to be the founder of 'scientific' history, whose beginnings can be traced to the 1820 s, archaeology as a scholarly pursuit surely cannot have begun before Schliemann. Moreover, the historical method is just about the same number of years older than the archaeologists'. Most contemporary archaeologists would throw up their hands at Schliemann's unseemly haste to dig down to the 'Homeric' finds (1871-74) - archaeological methodology began to develop, I would suspect, in horrified reaction to his bulldozer methods - but historical methodology was pretty much complete by that time. In 1876, for example, Sickel set down the editorial standards for editing charters, ${ }^{12}$ and in the following two years von Ficker published his Urkundenlehre, ${ }^{13}$ both of which, historians agree, still constitute the final word on how to edit royal charters and determine their authenticity. This does not, however, mean that history has all the advantages. Being a mature science, it is in grave danger of falling into comfortable complacency, going through the motions, but not actively developing the Grand Tradition. ${ }^{14}$ Historians therefore have to question their concepts ('culture') and intellectual constructs continuously, in order to convince themselves every day that their description of the past in present-day language does not falsify it. And they would do well to remind themselves that archaeology is a comparatively young field whose collection of sources cannot, by reason of its very youth, begin to compare with the historians' systematic collection of (written) sources, something which has been actively pursued for 200 years by now, ${ }^{15}$ with substantial continuing support from public funds. Archaeology, it seems to me, is still very much in the hunting-andgathering stage of its development. Excavations continuously turn up new and exciting finds, and archaeologists are demonstrating enthusiastically what it is possible to do with the sources one already has, such as the C14 dating of finds, trace element analysis of cloth and ceramics, DNA analysis of organic material and so forth. ${ }^{16}$ This is, if one thinks about it, also a form 
of (methodological) hunting and gathering, with particular focus on the natural sciences. However, archaeology being a young science, its practitioners are not called upon to do much more than demonstrate feasibility when presenting new methods. From a historian's point of view, this is very frustrating. Excited as they are to learn that the introduction of insect species (such as granary pests) into foreign environments like Iceland, resulting from overseas trade, can be documented archaeologically, they (unreasonably) clamour for an entomologically based systematic mapping of medieval trade routes. Can't be done, at least not yet. Archaeoentomology is simply too young a science, whose prime concern is properly to demonstrate what is feasible. More generally, the historians' demands for systematic surveying do not take the problem of funding into account. Again, I don't think that there is any way to reduce this friction. Both sides simply have to be aware of it.

The fact that archaeology and history do not mesh effortlessly is, however, no reason to give up hope. I think that both fields share common concerns, matters to which each side has something important to contribute and which the other side can take on board without strain. Let me highlight three.

(Hanseatic) historians and archaeologists are equally fascinated by the question of how industry and trade functioned at a practical level. It was Fritz Rörig who rebelling against Sombart's characterization of medieval merchants as shopkeepers at best $\mathrm{t}^{17}$ - pioneered the study of medieval Hanseatic overseas merchants, focusing both on the bread and butter, ${ }^{18}$ and the universal aspects of their trade. While trade, particularly overseas trade, has held its own in Hanseatic historiography, latterly turning towards network theory, ${ }^{19}$ the (industrial) production of goods in the Hanseatic area has lagged behind. This is particularly true of the (proto)industries located in inland Hanseatic towns. ${ }^{20}$ It seems to me that this would be a fruitful area for cooperation between Hanseatic historians and archaeologists, since each side will instantly - and effortlessly - see the point of cooperating, since both fields so obviously complement one another: archaeological finds can document industrial production in places no historian working from the written sources would ever have suspected it, ${ }^{21}$ and the written sources (especially guild regulations on cloth standards) can illuminate the archaeological finds.

Seals $^{22}$ are much studied by historians. ${ }^{23}$ However, they have not paid equal attention to all seals. The general rule is: the more prominent the owner, the more systematically studied. Hence, the seals of high-status people (kings, nobles, ecclesiastics etc.) and prominent, especially surviving institutions (town councils, hospitals etc.) have been well catalogued and described, whereas the so-called 'private seals' (those of the nonelite) have received much less attention. And - at least compared to the vast number of archaeological finds virtually no research at all has been conducted on cloth seals. Once again, both fields complement one another in this area. Indeed, there is a third, and related topic, in which both fields are (or ought to be) interested, namely merchants' marks, which have yet to be systematically catalogued. These are important not only archaeologically (for example, in order to identify the people who carved their marks in the soapstone portal of St. Olav's, Avaldsnes), but also sphragistically, ${ }^{24}$ since many merchants used their marks as the graphic emblem of their seals. Numberless merchants' marks have been copied and haphazardly published in the Hanseatic sources, ${ }^{25}$ but there is no catalogue of them, as there is, for instance, in the case of watermarks. ${ }^{26}$ Clearly, we are still in the hunting-and-gathering stage here. Despite all the catalogues, it is not an easy matter to identify the owner of a (private) seal on a charter in an archive (the catalogues only work in the direction person $\rightarrow$ seal, not in the direction seal $\rightarrow$ person), and the same is even more true of merchant's marks and cloth seals. There is great potential for co-operative spadework here. Since the technology is available to do non-invasive 3D-scans of seals (and seal matrixes), it should be straightforward to set up a database which would, on the one hand, identify an unknown seal (perhaps using fingerprint recognition software) and, on the other, serve as a repository for as yet unidentified seals. Merchants' marks are even easier, since they are usually comprised of straight lines. It ought not to be too difficult to create a scan program which imposes a merchant's mark on a standard matrix (for a primitive example, see Fig.1), ${ }^{27}$ yielding a machinesearchable bitmap ('To submit your query, draw the mark on the matrix and chose a level of fuzziness for the search') and a reproducible image, enhanced with descriptive metadata (e.g. name, date, source), so that the database could be queried by name ('Show me the mark of Conrat Ranss') or the search limited by date ('Show me all marks matching mine in the period 1400-1450').

Of course, one could classify the marks iconographically, as Piccard and his predecessors did with watermarks, ${ }^{28}$ although merchants' marks are harder to describe in natural language and hence to 


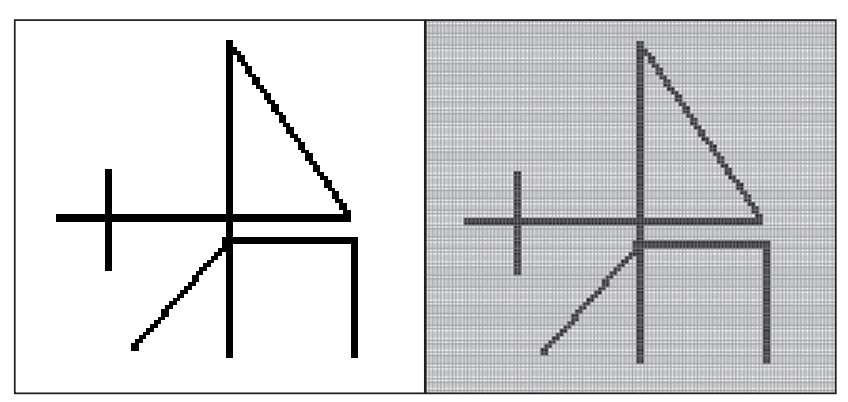

Fig. 1. Merchant's mark of Conrat Ranss as copied (left) and as imposed on a standard matrix.

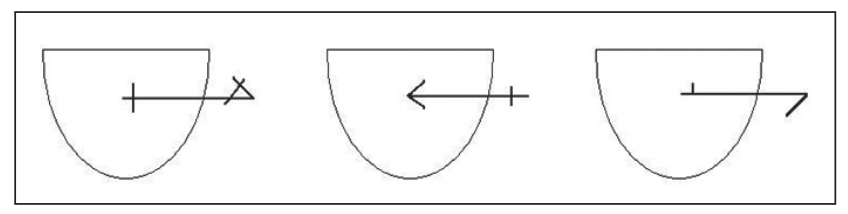

Fig. 2. Marks of Hildebrand, Severt and Zerghes Veckinchusen (re-drawing from Lesnikov and Stark 2013, lxxv).

categorize than watermarks, which can easily be broken down into intuitively comprehensible categories like oxhead, grapes, the letter P etc. A solution to this problem might be found by looking into the ordering of entries in Japanese and Chinese dictionaries, which, of course, have to deal with the quandaries of presenting pictograms in a way that allows words to be looked up. Two of the three methods employed by Far Eastern lexicographers seem promising: grouping by similar meaning and grouping by recurring graphic elements. Applied to merchants' marks this would imply either grouping iconographically related marks such as the Veckinchusen brothers', which are clearly variants of one another (Fig. 2), or by abstract graphic components such as the number of vertical and horizontal lines. ${ }^{29}$ Of course, modern computing allows you to do both. You simply have to plan in advance and add the appropriate metadata to each image as you go along.

At a more fundamental level, both history and archaeology ought to be concerned about the methodologically proper aggregation of incomplete data. However narrowly historians or archaeologists pose a question to the sources, neither field would dream of proclaiming that it possesses all the data required for a methodologically satisfying answer. There is always something missing, and, as a rule, quite a lot. ${ }^{30}$ Given that, both fields should continuously be asking themselves the fundamental question of just how robust their results are, since both are extrapolating from data which must be assumed to be incomplete and perhaps skewed. Now, I agree altogether that there is no solution to the problem of vital missing evidence, but that is no reason at all not to give some methodological thought to the problem. ${ }^{31}$ The danger is, of course, that we will simply avoid the quandary altogether and limit ourselves to a barren description of the evidence, the archaeologists doing a 'show and tell' with the objects and the historians summarizing charters (and the events reported in chronicles and annals) in chronological order, getting lost in the details and sighing, when asked, that the evidence is far too complex to permit generalization. That, it seems to me, is tantamount to an admission that one has failed (or not even tried) to compile the data at a methodologically defensible level of abstraction. Worse yet, failing to aggregate the data - and in so doing perhaps also to build intellectual bridges towards one another - raises the danger that each field will treat the other as an auxiliary science, very much junior to its august self. ${ }^{32}$ Thus, the historians will include images of archaeological finds as pretty pictures to spruce up their disquisitions on weightier topics, and the archaeologists will blithely cite some randomly chosen historian's musings as a general background to the description of the finds. And that, we would all surely agree, most decidedly does not constitute interdisciplinary work.

At this point, I would like to abstract away from the specific difficulties of interdisciplinary cooperation between historians and archaeologists and discuss the problem in a more general way. I am actuated to do so by the fact that interdisciplinary conferences have achieved canonical status in the eyes of scholars and funding bodies alike. Indeed, it is becoming increasingly difficult to obtain funding for conferences and projects alike if they fail to include some interdisciplinary aspect, irrespective of whether it makes any scholarly sense. In fact, however, the results of the conferences called in hope of providing a forum for an exchange of ideas between scholars from different fields and of laying the foundations of fruitful cooperation between academic disciplines are, to put it frankly, pretty shabby. Why isn't interdisciplinary cooperation simple and easy?

The first reason, it seems to me, is rooted in the sociology of academic life in the humanities at the moment. All of our fields are fighting for their existence as academic specialities against the onslaught of the natural sciences and other, seemingly more 'practical' disciplines. ${ }^{33}$ In such circumstances, there is a natural tendency of each field to concentrate on its core problems, grooming scholars expert in what are felt to be 
the central issues of the field (and who are expected to carry the flag into the next generation), while rigorously pruning away anything else. Of course, those of us with tenure could afford to range far afield, but by the time we've gotten a permanent job, we are too thoroughly socialized as historians (or whatever) to do so, however much lip service we pay to the desirability of cooperation between academic disciplines. In this context, indeed, it seems apt to modify Newton's laws of motion in order to formulate Jenks' laws of academic inertia: ${ }^{34}$

1. If no force is applied to them, all fields will continue in a straight line doing their own thing.

2. The larger the number of practitioners in a field, the harder it is to influence its direction.

3. If field A exerts a force on field B during a conference, field B will exert an equal and opposite force on field $\mathrm{A}$.

The result is complete inertia. There is, in my mind, a second and more compelling reason why scholars are reluctant to engage another field fully, which would, of course, be the prerequisite for true and fruitful interdisciplinary cooperation. The individual fields which are encouraged to work together draw their individual raison d'etre from the fact that they are (organizationally) degree-granting units within a university. ${ }^{35}$ As such, they have to attract the right kind of (graduate) students, impart to them an appropriate set of skills, a fact which is then certified by the granting of a degree, and finally to place them in employment in another department in the same field. What 'an appropriate set of skills' might be, is mandated by the field. In fact, one of the main factors which turns a field of study into a recognized discipline is a general consensus on the core skills students have to acquire, or, to put it another way, a standardization of training, which in turn makes the graduates of a given department recognizable as employable to others in the field and allows their work to be evaluated. ${ }^{36}$ That, in turn, locks the department into an oligopoly with all the other departments in the field. It cannot 'unilaterally choose to relax or alter standards without cheapening the degree in the disciplinary market, ${ }^{37}$ that is, without endangering the employment chances of its graduates.

This, of course, means that graduate students are locked into a programme of studies which - judging by the high-flying standards of interdisciplinarity is extremely rigid and narrow, and these constraints probably continue to exercise a baleful influence until one has attained tenure some fourteen or fifteen years after freshman year. Only then can a scholar afford to range far afield without risking professional ruin. But most don't. ${ }^{38}$ Is this surprising?

The second reason interdisciplinary work is not easy and simple is rooted in cognition science. Historical scholarship is very much a learning-by-doing field: you learn history as a student by doing it in contact with a scholar, writing papers and taking the scholar's criticism on board. ${ }^{39}$ Cognition scientists describe this sort of ability as tacit knowledge ${ }^{40}$ in the sense that its generation is so intimately caught up in its application that explicit, formal rules cannot be extracted. Anyone who has a driver's licence and learned on a stick-shift car will know what I mean: no matter how much the driving instructor tells you about how to press down the gas pedal gently and gradually let out the clutch, you still stall the car the first few times. After a while, you catch on, so that you kn ow (note that word!) how to drive a car. But you cannot encode that knowledge and communicate it in words any more than your driving instructor could. ${ }^{41}$ Now, of course, historians will immediately object that there are all sorts of handbooks on historical methods, starting with Droysen and Bernheim, and running, perhaps, down to Elton. ${ }^{42}$ I would submit that most of us haven't read these tomes, but we all instinctively know good history when we see it. And the reason for that is that, in the course of our education, we have absorbed a mental template ${ }^{43}$ one which tells us what problems are legitimate subjects for historical research and what facts are relevant in the context of a particular problem. We use our mental template to filter the source material and structure it, distinguishing signal from noise. Without that, we would only be permanently confused.

Now, I suspect that things are quite similar in archaeology. And there's the rub. The historical template and the archaeological template are different, indeed have to be different. Otherwise history and archaeology would not be two separate fields. But since each field is operating on the basis of a mental template out of which no explicit rules can be extracted, it is impossible to have an explicit interdisciplinary discussion. To be sure, the historian can sh ow the archaeologist how he works in a specific instance (and vice versa), but knowledge of the other's template can only be generated by personal contact over a period of time. ${ }^{44}$ A conference is nowhere near long enough. Therefore interdisciplinary conferences are doomed to failure.

This is not to say all academic disciplines are fated to remain closed books to one another forever. There are ways of slashing through the Gordian knot. 
Those foolhardy enough to read my more recent papers ${ }^{45}$ know how shamelessly I have hijacked economic models. It all started on a long train trip up to Lübeck. For reasons which escape me now, I had taken along a copy of an article by Davis and North to read on the way. ${ }^{46}$ Picture me, then, if you will, rattling along on the train, becoming increasingly excited and jabbing in one 'That's just like the Hanse!' comment after another in the margins. My point is: other fields can indeed illuminate your own work, but if you don't instantly see it, it's probably not there.

However, one cannot blithely rely on inspiration to strike every time it is required. Consequently, it is well not to underestimate the difficulties of acquiring a sufficient understanding of a different field to enable interdisciplinary cooperation. This understanding is not limited to a command of the other field's technical language or a broad familiarity with its sources and problems. The essential skill is the ability to pose the sort of questions which practitioners in the other field ask. Let me point to two examples in order to illustrate what I mean. ${ }^{47}$

When I took a bold leap from the economic history of the fifteenth century into the economic history of the twenty-first, ${ }^{48}$ I was confronted with the need to understand a lot of monetary economics. Even with the help of an indulgently patient colleague in economics, it took me two long years to begin to think like an economist. In the end (I persuade myself), I had learned how to ask economists' questions. This had an immediate pay-off, since the next project involved papal plenary indulgences, and these cast a brilliant light on just how different the questions posed by practitioners in two fields can be. Starting in 1300, the popes began to grant indulgences, releasing the repentant and shriven sinner from all temporal punishment accrued by reason of sin. Ultimately, as spiritual exercises (fasting, praying, giving alms to the poor) yielded to monetary payments as a way of earning the indulgence, this led to Luther's protest against the Church's penitential practices (in the 95 Theses) and the Reformation. Now, when church historians look at the sources for the various indulgence campaigns from 1300 to 1517, they focus on intellectual history, asking what theological arguments were forwarded to justify indulgences and how these relate to the Church's penitential practice through the centuries. When economists look at the same sources, they focus on the flow of funds, asking what effect the departure of large amounts of cash over the Alps each year might have had on investment, interest rates and ultimately on gross domestic product in Germany. Now, I think any neutral observer would agree that these are very different approaches: no economist would ever dream of asking the church historians' questions and vice versa. In my view, however, fruitful interdisciplinary work requires the ability to switch hats. ${ }^{49}$ This is a skill not acquired without effort.

Economists like to ask about incentives, and it is worth considering this in the context of interdisciplinary cooperation. What incentives do scholars have to cooperate with those in other fields $?^{50}$ In order to give a satisfying, non-facile answer, we will have to delve deep. One of the salient characteristics which mark off homo sapiens from all other animals is its intense, life-long curiosity about its environment. ${ }^{51}$ Now, the notable thing about human curiosity is not that it is present - all mammals explore their environment - but that it is persistent. Young apes and monkeys are just as inquisitive as young humans, but human curiosity never ceases, indeed increases with age, whereas it drops off in monkeys and apes as they mature physically. ${ }^{52}$ Now, the point to be made here is that human curiosity is playful, that is to say: pursued for its own sake, with no other goal in view. Moreover, exploring the unfamiliar and rendering it familiar is most enjoyable when there is a big pay-off for a small effort, a balloon, for instance, which flies across the room at the slightest touch of an infant hand, a toy police car which makes the loud noise of a siren when pushed lightly. ${ }^{53}$ This urge to explore and understand motivates all forms of human intellectual endeavour, extending even into the natural sciences at the highest level. ${ }^{54}$ But the play element never disappears: curiosity is exercised for its own sake, and the bigger the bang for a buck, the better. ${ }^{55}$

So, the lesson to be drawn is that interdisciplinary cooperation has to be playful, pursued for its own sake, and that it works best when there is a big pay-off for a small effort. The incentives (to speak for a moment in the language of the economists) are greatest when utility is immediate and evident. This has, however, to hold true for both (or all) sides. Roping in civil engineers, materials scientists and meteorologists for consultation on building the Brooklyn Bridge does not constitute interdisciplinary work. The consultants are called upon to contribute their own little bit and are not expected to comment upon the contributions of other consultants. Crucially, there is no pay-off for them. Consequently, any interdisciplinary thinking balancing, say, the expected stresses which might be occasioned by extreme weather against the strengths 
of the materials to be employed - only goes on within a very narrowly circumscribed circle, comprising, perhaps, the project manager, the representatives of the funding body and the architect.

Now, this is easy to see if we limit ourselves to engineering projects. My contention, however, is that the top-down, imperative demands for interdisciplinarity threaten to reduce science to engineering generally. Note that most of the projects deemed by the votaries of inter- and transdisciplinarity to be worthy of admiration and imitation involve a clearly defined goal (building the atom bomb, dealing with climate change or diseases $)^{56}$ - often enough imposed from outside with the claim that it would serve some societal purpose or solve a real-world problem ${ }^{57}$ - and equally precisely defined contributions by the cooperating fields to the overall project. The reason is that resources are scarce and, for legal reasons, the expenditure of public funds has to be planned in advance in great detail and justified periodically. This exigency, in turn, has the effect of shifting power up to deans, university presidents, funding bureaucracies ${ }^{58}$ and, ultimately, to politicians, who are, in the end, accountable to the voters. With power, of course, goes the right to make decisions about the direction research is to take, by granting or withholding funding. The farther one goes up the line, of course, the greater the pressure to invent problem definitions and labels that appeal to the public and its representatives. ${ }^{59}$ This raises the disturbing question of when mere fashionable project labelling (with no change in substance) will shade over into craven pandering to the public mood, thus yielding control of science to the restless tumbleweed of (manipulated) public opinion. ${ }^{60}$ Whether this has already happened or not is a matter for debate. ${ }^{61}$ What seems clear to me is that the dynamics of acquiring and administering funds for research projects constitute a powerful incentive to reduce science to engineering. Since this cannot but inhibit human curiosity and channel it into solving specific problems perceived by the public and the politicians as being suited serve the societal goal and/or solve a real-world problem of the moment, it is, in my view, wildly counterproductive. The opportunity costs (to use an economist's terms) are simply not to be contemplated.

So is all lost? Should we throw up our hands in despair and let the entire research budget of the United States be used - I put forward the worst-case scenario here to disprove Darwin's theory of evolution and the reality of man-made climate change? I'm not sure things are in such a parlous state, at least as of the present. What is clear to me is that - pushed to the extreme - top-down mandated interdisciplinarity is self-defeating. ${ }^{62}$

Therefore, it seems to me, it is incumbent on us to be just a little more modest. Let us - as historians and archaeologists - seek out projects which are of perceptible use to both sides. I have suggested a few in this paper, and I am confident my colleagues will come up with more. Let us furthermore engage with the central concepts of the other's field, and ask their questions of our sources. Historians would, for instance, do well to consider the long-wave phenomena which the archaeologists are able to capture. They would also do well to consider the economists' interest in stability. And economists would do well to realize that they, too, are historians and that economic enquiry is not limited to the period after 1980. The main point is to start small, keep the rewards flowing equably and trust to human curiosity to sniff out further areas of cooperation.

\section{Acknowledgements}

I would like to thank Mitchell Ash (Vienna) for a very useful critique of an earlier version of this paper. Other intellectual debts (and there are many) are acknowledged in the endnotes.

\section{Endnotes}

${ }^{1}$ I am not the first to have noticed this: see Wenskus 1979 , 641.

${ }^{2}$ I hasten to add that I am not the first person to pose this question: see Wenskus 1979.

${ }^{3}$ Ash (in press) provides an apt example: 'In a programmatic document, the National Research Council advocated such a norm in 2009: "The members of interdisciplinary teams learn from each other to produce new approaches to a problem that would not be possible through any of the single disciplines. Typically, this process begins with team members first learning the language of each other's disciplines, as well as the assumptions, limits and valid uses of those disciplines' theoretical and experimental approaches" (cited in Graff 2015, 4). Graff falsely attributes this statement to the National Institutes of Health.'

${ }^{4}$ I hasten to add that I do not impute imprecision to archaeologists generally. It is indisputable, for instance, that their calibration of C14 measurements is exacting enough to satisfy anyone. As Mitchell Ash points out to me (in a private communication) the meaning of the term 'precision' shifts according to what you're being precise about, something philosophers call 'contexts of use'. Nonetheless, I would counter, the results of the most precise of $\mathrm{C} 14$ measurements yield at best a rough date, as signalled by the ' \pm ' in the result. And it is worth pointing out that we are here discussing perceptions of another field's results, not the precision or accuracy of those results themselves. 
${ }^{5}$ I am grateful to Kevin Smith (Brown University) for pointing this out to me.

${ }^{6}$ This is not an undisguised blessing, as Smith 2004 points out, comparing the written and archaeological records bearing on state formation in Iceland in the period $c$. 1000-1264. Each field sees part of the whole and misses part.

${ }^{7}$ Let me emphasize, in order to assuage any possible injured feelings, that I am spotlighting historians' perceptions of archaeologists.

${ }^{8}$ Let me add that I am not unaware that there are social historians working on the daily life of ordinary people in the Middle Ages. However, the fact remains that any trawl in the archives turns up vastly more information on the prominent (including merchants) than on the obscure.

9 The exhumation of Richard III's skeleton is a good example. While boisterous claims were made that this discovery would lead to a complete reassessment of the monarch (e.g. by Philippa Langley of the Richard III Society and spiritus rector of the dig [albeit not an archaeologist]: 'We're going to completely reassess Richard III, we're going to completely look at all the sources again, and hopefully there's going to be a new beginning for Richard as well.' < http://www.bbc.co.uk/ news/uk-england-leicestershire-21063882>), most historians would, I suspect, retort that the discovery of the king's bones does not add one jot to our knowledge of the man or his times - after all, everyone already knew he died at the Battle of Bosworth Field in 1485, and whether he was a hunchback or not is not an important historical question - and that scholarly energy might be put to better use examining the masses of records, as yet unexplored, dating from his reign and preserved in The National Archives.

${ }^{10}$ This also holds true, by the way, for trade with England. The English sources, although immeasurably richer, still don't yield much information at all about trade links with the North Atlantic.

${ }^{11}$ I must acknowledge my debt to Mark Gardiner for bringing this point to my attention and beg his forgiveness for my cheekiness in developing it here.

${ }^{12}$ Sickel 1876.

${ }^{13}$ von Ficker 1877; von Ficker 1878.

${ }^{14}$ By way of contrast, archaeology is still busily throwing out roots, for instance to geology and zoology.

${ }^{15}$ As an example illustrating the unending labour expended in order to collect all possible historical sources for German history systematically, consider the far-flung journeys of the peripatetic Ludwig Bethman to numberless European libraries and archives: Fuhrmann 1996, 37-44.

${ }^{16}$ I am grateful to Kevin Smith for providing these examples.

${ }^{17}$ Hammel-Kiesow 2008, 18f.

${ }^{18}$ This is best exemplified by two editions: Rörig 1925 and Rörig 1931. For two contrasting views of Rörig see Noodt 2007 and Müller-Mertens 2003, 25-30. As Rörig's last doctoral candidate, Müller-Mertens is reverential, while Noodt is more critical. See also Paulsen 2017, who is even more critical.

${ }^{19}$ Selzer and Ewert 2007; Selzer and Ewert 2010a; Selzer and Ewert 2010b; Jahnke 2010; Burkhardt 2010.
${ }^{20}$ Exceptions are Holbach 1993 and Holbach 1994; Huang 2015; Beddies 1996.

${ }^{21}$ Wenskus 1979, 648f., 656 touched on this issue.

${ }^{22}$ Thanks to Michèle Hayeur Smith and Kevin Smith (Brown University) for suggesting this.

${ }^{23}$ For a general introduction to the subject see von Brandt 1973, 132-149, and for a brief overview of the older bits of the immense literature see Jenks 1982.

${ }^{24}$ I.e. in relation to the study of seals.

${ }^{25}$ Almost every list of damages merchants suffered at the hands of pirates or enemies includes a drawing of the marks which had been chiselled into the barrelheads, e.g. HUB VII,1 no. $767 \$ 25$, p. 428. Kuske 1923, 366-386 and table I-VII records just under 800 merchants' marks from Cologne in the thirteenth to sixteenth centuries alone.

${ }^{26}$ See <http://www.piccard-online.de/start.php>.

27 This is, as I have only just discovered, a standard function of so simple a graphics programme as MS Paint (ctrl $+\mathrm{G}$ does the trick). One would only have to set the dimensions of the standard matrix in pixels.

${ }^{28}$ See <http://www.piccard-online.de/struktur. php? sprache $=>$.

${ }^{29}$ Perhaps a note of caution is in order here, lest we proceed in undue haste, mechanically classifying merchants' marks according to some abstract system of our own devising. Just at first glance, two facts about these marks seem to spring to the eye. First, there were a lot of them at any given time. Second, no one ever seems to have confused one mark with another, that is to say, they were sufficiently individuated to avoid confusion. When one thinks about it, this is fairly remarkable. Consider a merchant surveying all the barrels and bundles on the quayside, trying to find the three his associate sent him. The achievement is even more remarkable if one considers that all sorts of merchants right around the Baltic and the North Sea invented their own marks in (partial or complete) ignorance of other merchants' marks. And yet these marks remained sufficiently individuated that there are no signs of confusion in the historical record. Since we have grave difficulties distinguishing between myriad marks (just you try your hand at Kuske 1923, 366-86 and table I-VII), we are clearly not seeing these things the way medieval merchants did. So we should think about inductively working out just how medieval merchants saw these marks and make that the basis of our classification. Perhaps some inspiration may be drawn from the way publishers organized the tens of thousands of cattle brands current in the American West around 1900, each of which consisted of a very few visual elements, in their annual brand books (Bryson 1994, 184).

${ }^{30}$ Nonetheless, historians proceed in fact from the assumption that what is transmitted (indeed, what has been edited) fully represents the whole, i.e. that the vagaries of recording and transmission have introduced no significant distortions: Jenks et al. 2004, 153f.; Esch 1999, 134.

${ }^{31}$ For an exploration of some of the issues involved here - especially the degree to which the selection of documents for an edition and the descriptive language employed by the editor subtly influence the 
interpretation of the sources by historians - see Huang and Kypta 2011, 221-25 and Groth 2017, 81-87. Each age may, as von Ranke 1854 famously remarked, be 'unmittelbar zu Gott', that is to say only to be understood by proceeding from that age's own perspective and not by way of reference to perennially valid principles or moral precepts, but this is decidedly not true of editions. They are, almost without exception, very much children of their day. What is selected, and how the documents are described by the editor, depends to a dismayingly high degree on what historical questions happen to be fashionable at the moment.

${ }^{32}$ An apt example of this is provided (albeit unwittingly) by Wenskus 1979, esp. 656, who views interdisciplinary co-operation between history and archaeology as being resolutely uni-directional. Archaeologists can contribute to historians' understanding of the past in various technical matters, but as a field archaeology is consigned explicitly to the status of an auxiliary science ('die Archäologie [kann] dem Mittelalterhistoriker als "Hilfswissenschaft" dienen'). This is, however courtly the wording, extremely demeaning to archaeologists.

${ }^{33}$ On this subject see Davidson and Savonick 2017, 162.

${ }^{34}$ In presenting this law, I am emboldened by the shining example of Paul Krugman, who also made a serious point in a not altogether serious manner. As the Nobel prize winner himself states, 'It should be noted that, while the subject of this article is silly, the analysis actually does make sense. This article, then, is a serious analysis of a ridiculous subject, which is of course the opposite of what is usual in economics' (Krugman 2010, 1119).

${ }^{35}$ The discussion in this paragraph is largely drawn from Turner 2000, albeit with different emphases.

${ }^{36}$ Ibid., 59.

${ }^{37}$ Ibid., 54 .

${ }^{38}$ On the degree to which the leading practitioners in a field (here economics) remain intellectually chained to the curriculum they followed as undergraduates see Eichengreen 2012 and Earle et al. 2017.

${ }^{39}$ Note that this also includes microgestures which we do not consciously perceive.

${ }^{40}$ The classic study is Polanyi 1966.

${ }^{41}$ For other famous examples of unencodable (tacit) knowledge see Collins 1975 and Collins 2001.

${ }^{42}$ Droysen 1882; Bernheim 1908; Elton 1967.

${ }^{43}$ I have borrowed this term from Walsh 1995, 281 . Kuhn would designate the same phenomenon as a paradigm: Kuhn 1970, viii, 10, 15-17, 23-29, 175. Lam calls it 'embodied knowledge' in contrast to encodeable 'embrained knowledge': Lam 2000, 492.

${ }^{44}$ See Collins 2001; Goffin and Koners 2011.

${ }^{45}$ Jenks 2005; Jenks 2013; Jenks 2014a; Jenks 2014b;

${ }^{46}$ Davis and North 1970.

${ }^{47}$ I must beg the reader's indulgence in providing examples which are, frankly, autobiographical. I do so only because I think they are good illustrative examples and because I am in the happy position of being well informed about the details. Wenskus 1979, $614 \mathrm{f}$ provides another example: Detlef Ellmers.
${ }^{48}$ This resulted in Jenks 2012.

${ }^{49}$ The reader will judge for himself or herself how well I have succeeded in so doing: Jenks 2018, 754-68. At the moment, all that is clear is that neither the church historians, nor the economists betray any noticeable enthusiasm for this sort of interdisciplinary thinking. A reaction from the economists has yet to materialize, and the only comment from the church historians was a toneless 'Well, I suppose it is a different point of view.'

${ }^{50}$ I hasten to exclude from consideration the opportunistic 'looting parties' formed for the sole purpose of garnering huge grants: Ash (in press) at n. 9.

${ }^{51}$ In the following paragraph, I summarize Morris 1967, 113-23.

${ }^{52}$ Ibid., 114

${ }^{53}$ Ibid., 116.

${ }^{54}$ Dick Feynman, the CalTech physicist, tells the story of being in a cafeteria in Cornell and watching some bright spark toss one plate after another in the air. Now, Cornell has a prominently dark red coat of arms, which was incorporated into the college's crockery. Consequently, Feynman was able to notice that the plates spun faster than they wobbled. Just for fun ('I had nothing to do...'), Feynman worked out that, at a very slight angle, the rate of spin was twice that of the wobble. That led him to consider the forces that made the spin-wobble-relationship come out exactly to 2:1. Ultimately, this led to the Nobel prize in physics. But why did Feynman do it? In response to a question Hans Bethe (himself no slouch of a physicist) asked about why all of this was important, Feynman responded, 'There's no importance whatsoever. I'm just doing it for the fun of it.' Feynman 1985, 173ff.

${ }^{55}$ Morris 1967, 122.

${ }^{56}$ See Klein 2017, 23-25, 30; Huutoniemi et al. 2010, 84. Note, however, Feynman's remark about building the atom bomb: 'All science stopped during the war except the little bit that was done at Los Alamos. And that was not much science; it was mostly engineering.' Feynman 1985, 108.

${ }^{57}$ See Ash (in press) at n. 6, who describes this phenomenon as 'top-down or policy-driven ID [interdisciplinarity] or MD [multidisciplinarity]' (at n. 8).

${ }^{58}$ Jacob 2017, 37f. Ash (in press) third paragraph after $n$. 9, citing Lamont 2009, 211 who makes the intriguing point that the negotiations between grant applicants and research funding bureaucracies (including review panels) also constitute a form of interdisciplinarity.

${ }^{59}$ Weingart 2000, 38.

${ }^{60}$ Ibid.

${ }^{61}$ It is disturbing to observe just how far grandstanding legislators like Lamar Smith (R-Texas) are willing to go in pursuing 'wasteful' (i.e. not 'practical') research funded by NEH grants.

${ }^{62} \mathrm{I}$ am making a different point here than Weingart 2000, 40. He argued that interdisciplinarity engenders specialization. My contention is that extreme interdisciplinarity excludes most participants in a given project from interdisciplinarity and strangles innovation. 


\section{References}

Ash, M. G. (in press), Interdisciplinarity in Historical Perspective, in M. MacLeod, M. Merz, U. Mäki, M. Nagatsu (eds), Investigating Interdisciplinary Practice: Methodological Changes. Special Issue of Perspectives on Science.

Beddies, T. 1996. Becken und Geschütze. Der Harz und sein nördliches Vorland als Metallgewerbelandschaft in Mittelalter und früher Neuzeit. Europäische Hochschulschriften III/698. Frankfurt: Peter Lang, 1996.

Bernheim, E. 1908. Lehrbuch der historischen Methode und der Geschichtsphilosophie, 6th ed., 2 vols., Leipzig: Duncker \& Humblot

von Brandt, A. 1973. Werkzeug des Historikers. Eine Einführung in die Historischen Hilfswissenschaften. Stuttgart: Kohlhammer.

Bryson, B. 1994. Made in America. London: Secker \& Warburg.

Burkhardt, M. 2010. Der hansische Bergenhandel im Spätmittelalter. Handel - Kaufleute - Netzwerke. Quellen und Darstellungen zur hansischen Geschichte NF 60. Köln: Böhlau.

Collins, H. M. 1975. The TEA Set: Tacit Knowledge and Scientific Networks. Science Studies 4(2), 165-186.

Collins, H. M. 2001. Tacit Knowledge, Trust and the Q of Sapphire. Social Studies of Science 31(1), 71-85.

Davidson, C. N. and Savonick, D. 2017. Digital Humanities. The Role of Interdisciplinary Humanities in the Information Age, in R. Frodeman (ed.), The Oxford Handbook of Interdisciplinarity. 2nd edition, 159-172. Oxford: Oxford University Press.

Davis, L. and North, D. 1970. 'Institutional Change and American Economic Growth: A First Step Towards a Theory of Institutional Innovation'. Journal of Economic History 30, 131-149.

Droysen, J. G. 1977. Historik. Vorlesung über Enzyklopädie und Methodologie der Geschichte (1882), ed. Peter Leyh, Stuttgart: Frommann-Holzboog.

Earle, J., Moran, C. and Ward-Perkins, Z. 2017. The Econocracy. On the Perils of Leaving Economics to the Experts. Manchester: Manchester University Press.

Eichengreen, B. 2012. Economic History and Economic Policy. Journal of Economic History 72(2), 289-307.

Elton, G. R, 1967, The Practice of History, Sydney: Sydney University Press.

Esch, A. 1999. Der Umgang des Historikers mit seinen Quellen. Über die bleibende Notwendigkeit von Editionen, in L. Gall and R. Schieffer (eds.), Quellenedition und kein Ende? Symposion der Monumenta Germaniae Historica und der Historischen Kommission bei der Bayerischen Akademie der Wissenschaften München 22./23 Mai 1998. Historische Zeitschrift Beihefte NF 28, 129-147. Munich: Oldenbourg.

Feynman, R. P. 1985. Surely You're Joking, Mr Feynman! Adventures of a Curious Character. New York: Norton.

von Ficker, J. 1877. Beiträge zur Urkundenlehre, vol. 1. Innsbruck: Wagner.

von Ficker, J. 1878. Beiträge zur Urkundenlehre, vol. 2. Innsbruck: Wagner.
Fuhrmann, H. 1996. 'Sind eben alles Menschen gewesen'. Gelehrtenleben im 19. und 20. Jahrhundert dargestellt am Beispiel der Monumenta Germaniae Historica und ihrer Mitarbeiter. Munich: Beck.

Goffin, K. and Koners, U. 2011. Tacit Knowledge, Lessons Learnt, and New Product Development', Journal of Product Innovation Management 28, 300-318.

Graff, H. J. 2015. Undisciplining Knowledge: Interdisciplinarity in the Twentieth Century. Baltimore: Johns Hopkins University Press.

Groth, C. 2017. Die Lübecker Ratsurteile. Wilhelm Ebel und eine wissenschaftliche Geschäftsführung 'ohne Auftrag'? Hansische Geschichtsblätter 135, 75-113.

Hammel-Kiesow, R. 2008. Die Hanse, 4th ed. Munich: Beck. Holbach, R. 1993. Zur Handelsbedeutung von Wolltuchen aus dem Hanseraum, in S. Jenks and M. North (eds), Der hansische Sonderweg? Beiträge zur Sozial- und Wirtschaftsgeschichte der Hanse. Quellen und Darstellungen zur hansischen Geschichte NF 39, 135-190. Cologne: Böhlau.

Holbach, R. 1994. Frühformen von Verlag und Großbetrieb in der gewerblichen Produktion (13.-16. Jahrhundert). Stuttgart: Steiner.

Huang, A. 2015. Die Textilien des Hanseraums. Produktion und Distribution einer spätmittelalterlichen Handelsware. Quellen und Darstellungen zur hansischen Geschichte NF 71. Köln: Böhlau.

Huang, A. and Kypta, U. 2011. Ein neues Haus auf altem Fundament. Neue Trends in the Hanseforschung und die Nutzbarkeit der Rezeßeditionen. Hansische Geschichtsblätter 129, 213-229.

Huutoniemi, K., Thompson Klein, J., Bruun, H. and Hukkinen, J. 2010. Analyzing interdisciplinarity: Typology and indicators. Research Policy 39, 79-88.

Jacobs, J. A. 2017. Sidebar: the Need for Disciplines in the Modern Research University, in R. Frodeman (ed.), The Oxford Handbook of Interdisciplinarity, 35-39. Oxford: Oxford University Press. 2nd ed.

Jahnke, C. 2010. Handelsnetze im Ostseeraum, in G. Fouquet and H.-J. Gilomen (eds), Netzwerke im europäischen Handel des Mittelalters. Vorträge und Forschungen 72, 189-212- Ostfildern: Thorbeke.

Jenks, S. 1982. Frauensiegel in den Würzburger Urkunden des 14. Jahrhunderts. Zeitschrift für bayerische Landesgeschichte 45, 541-553.

Jenks, S. 2005. 'Transaktionskostentheorie und die mittelalterliche Hanse'. Hansische Geschichtsblätter 123, $31-42$

Jenks, S. 2012. Banken und Finanzkrisen (Handel, Geld und Politik 11). Lübeck: Schmidt-Römhild.

Jenks, S. 2013. Small is beautiful: Why small Hanseatic firms survived in the late middle age', in WubsMrozewicz, J. and Jenks, S. (eds), The Hanse in Medieval and Early Modern Europe, 191-214. Leiden: Brill.

Jenks, S. 2014a. Die Hanse als kybernetische Organisation, in O. Auge (ed.). Hansegeschichte als Regionalgeschichte. Frankfurt: Peter Lang.

Jenks, S. 2014b. Die Distributionsrevolution des 15. Jahrhunderts. Hansische Geschichtsblätter 132, 47-78.

Jenks, S. 2018. Documents on the Papal Plenary Indulgences 1300-1517 Preached in the Regnum Teutonicum. Leiden: Brill. 
Jenks, S., Kapfenberger, D. and Link, C. 2004. Technischer Fortschritt vs. editorischer Rückschritt. Eine falsche Alternative. Hansische Geschichtsblätter 122, 147-162.

Klein, J. 2017. Typologies of Interdisciplinarity. The Boundary Work of Definition, in R. Frodeman (ed.), The Oxford Handbook of Interdisciplinarity, 21-34. Oxford: Oxford University Press. 2nd ed.

Krugman, P. 2010. The Theory of Interstellar Trade. Economic Inquiry 48(4), 1119-1123.

Kuhn, T. S. 1970. The Structure of Scientific Revolutions (International Encyclopedia of Unified Science 2/2), 2nd revised ed. Chicago: University of Chicago Press.

Kuske, B. (ed.) 1923. Quellen zur Geschichte des Kölner Handels und Verkehrs im Mittelalter. Dritter Band: Besondere Quellengruppen des späteren Mittelalters. Bonn: Hansteiner.

Lam, A. 2000. Tacit Knowledge, Organizational Learning and Societal Institutions: An Integrated Framework. Organization Studies 21(3), 487-513.

Lamont, M. 2009. How Professors Think. Inside the Curious World of Academic Judgement. Cambridge: Harvard University Press.

Lesnikov, M. P. and Stark, W. (eds) 2013. Die Handelsbücher des Hildebrand Veckinchusen. Kontobücher und übrige Manuale. Köln: Böhlau.

Morris, D. 1967. The Naked Ape. London: Corgi.

Müller-Mertens, E. 2003. Die Hanse in europäischer Sicht. Zu den konzeptionellen Neuansätzen der Nachkriegszeit und zu Rörigs Konzept, in E. MüllerMertens and H. Böcker (eds), Konzeptionelle Ansätze der Hanse-Historiographie, 19-43. Trier: Porta Alba.

Noodt, B. 2007. Fritz Rörig (1882-1952): Lübeck, Hanse und Volksgeschichte. Zeitschrift des Vereins für Lübeckische Geschichte und Altertumskunde 87, 155180.

Paulsen, R. 2017. Fritz Rörig, in M. Fahlbusch, I. Haar and A. Pinwinkler (eds), Handbuch der völkischen Wissenschaften. Akteure, Netzwerke, Forschungsprogramme, 657-661. Berlin: De Gruyter.

Polanyi, M. 2009. The Tacit Dimension. Chicago 1966, ND Chicago (Terry Lectures 1962).

Von Ranke, L. 1971. Über die Epochen der neueren Geschichte. Historisch-kritische Ausgabe, ed. Schieder, T. and Berding, H. (Leopold von Ranke, Aus Werk und Nachlaß 2), Munich: Oldenburg.

Rörig, F. 1925. Das älteste erhaltene deutsche Kaufmannsbüchlein. Hansische Geschichtsblätter 50, 12-66.
Rörig, F. 1931. Das Einkaufsbüchlein der NürnbergLübecker Mulichs auf der Frankfurter Fastenmesse des Jahres 1495. Breslau: Hirt.

Selzer, S. and Ewert, U. C. 2007. Netzwerkorganisation im Fernhandel des Mittelalters: Wettbewerbsvorteil oder Wachstumshemmnis? in H. Berghoff and J. Sydow (eds), Unternehmerische Netzwerke. Eine historische Organisationsform mit Zukunft? 45-70. Stuttgart: Kohlhammer.

Selzer, S. and Ewert, U. C. 2010a. Wirtschaftliche Stärke durch Vernetzung. Zu den Erfolgsfaktoren des hansischen Handels, in M. Häberlein and C. Jeggle (eds), Praktiken des Handels. Geschäfte und soziale Beziehungen europäischer Kaufleute in Mittelalter und früher Neuzeit, 3-69. Konstanz: UVK.

Selzer, S. and Ewert, U. C. 2010b. Netzwerke im europäischen Handel des Mittelalters. Konzepte Anwendungen - Fragestellungen, in G. Fouquet and H.-J. Gilomen (eds), Netzwerke im europäischen Handel des Mittelalters, 21-47. Ostfildern: Thorbeke.

Sickel, T. 1876. Programm und Instruction der DiplomataAbtheilung. Neues Archiv 1, 427-498.

Smith, K. 2004. Patterns in Time and the Tempo of Change. A North Atlantic Perspective on the Evolution of Complex Societies, in J. R. Mathiew and R. E. Scott (eds), Exploring the Role of Analytical Scale in Archaeological Interpretation, 83-99. Oxford: Archaeopress.

Turner, S. 2000. What Are Disciplines? And How Is Interdisciplinarity Different? in P. Weingart and N. Stehr (eds), Practising Interdisciplinarity, 46-65. Toronto: Toronto University Press.

Walsh, J. P. 1995. 'Managerial and Organizational Cognition: Notes from a Trip Down Memory Lane'. Organization Science 6:3, 280-321.

Weingart, P. 2000. Interdisciplinarity: The Paradoxical Discourse in: P. Weingart, N. Stehr (eds.), Practising Interdisciplinarity. Toronto: University of Toronto Press.

Wenskus, R. 1979. Randbemerkungen zum Verhältnis von Historie und Archäologie, insbesondere mittelalterlicher Geschichte und Mittelalterarchäologie, in H. Jankuhn and R. Wenskus (eds), Geschichtswissenschaft und Archäologie. Untersuchungen zur Siedlungs-, Wirtschafts- und Kirchengeschichte. 637-657. Sigmaringen: Thorbecke. 